\title{
ACTUALIZACION
}

\section{Encefalitis equina venezolana}

\author{
Gerzaín Rodríguez ${ }^{1}$, Jorge Boshell²
}

\section{Definición}

Es una zoonosis viral que tiene como huéspedes principales a los equinos, en los cuales produce una severa meningoencefalomielitis epizoótica que puede alcanzar una letalidad del $80 \%$. Los equinos son amplificadores del virus causal, que es transmitido al humano por diferentes tipos de mosquitos. El humano desarrolla enfermedad sistémica, aguda y febril, generalmente de poca gravedad, pero que puede ser letal en el $0,2-1 \%$ de los enfermos.

\section{Historia}

La encefalitis equina venezolana ha sido una enfermedad ancestral en Suramérica. Sanmartín (1) cita versos de don Juan Castellanos, escritos hacia 1590 y en donde se describen los periodos de excitación y "volteadera" de los caballos, versos que se referían a la expedición a los Ilanos de don Gonzalo Jiménez de Quesada (1569-1571) en la cual, de 1.100 caballos con los que partió, apenas regresó con dieciocho.

Las primeras descripciones clínicas de la enfermedad las hizo J.E. Albornoz, en equinos del Valle del Cauca, Tolima, Huila y Bolívar, en 1935, enfermedad a la que llamó "peste loca de las bestias" (2). El virus causal fue aislado del cerebro de un caballo e identificado como distinto de los productores de otras encefalitis equinas, por Kuber y Ríos en Venezuela, en 1939, durante una epizootia en La Guajira venezolana (3). En 1941 se confirmó en Colombia la presencia del virus, que fue aislado del

1 Laboratorio de Patología, INS. Profesor titular de cátedra, Departamento de Patología, Facultad de Medicina, Universidad Nacional, Bogotá.

2 Laboratorio de Virología, INS. cerebro de un caballo muerto con "peste loca" en Bogotá (4). Este aislamiento fue confirmado por Kubes en Venezuela.

La enfermedad humana se conoce desde 1943, como accidente de laboratorio y desde 1944 como posible enfermedad natural, pero, sin suficiente confirmación de laboratorio (5).

La primera demostración de la enfermedad en humanos, en condiciones naturales y epidémicas, se hizo en Colombia, en Espinal (Tolima) en 1952 (6). El virus se aisló de una paciente febril y se demostraron anticuerpos en otras 10 personas. Entre 1955 y 1962 se hicieron varios aislamientos del virus en humanos con infección natural, en San Vicente de Chucurí (Santander) (7), aislamientos repetidos en 1971 en Puerto Boyacá (Boyacá) por el mismo autor.

En 1962 se presentó una epidemia en La Guajira colombo-venezolana que originó, por lo menos, 3.000 casos de enfermedad humana en Colombia con 10 defunciones y cerca de 32.000 casos en Venezuela con 190 muertos $(0,6 \%)(8)$. Wenger describió en esta epizoodemia la necrosis cerebral masiva del feto, en los hijos de madres que padecieron la infección o la enfermedad en diferentes fechas del embarazo (9).

Entre 1967-70 el virus se aisló de humanos y de animales salvajes y centinelas en el valle del Magdalena medio, Valle del Cauca, Catatumbo y la Sierra Nevada de Santa Marta. Se estudió muy bien la epizoodemia de El Carmelo (Candelaria) y Atuncelas (Dagua) a $30-35 \mathrm{~km}$ de Cali, respectivamente, con más de dos centenares de casos humanos. En Atuncelas se aisló el virus de más de 10 especies de mosquitos y se demostró que los simúlidos (jejenes) pueden transmitir el virus (10). 
Entre 1970-74 se estudiaron epizootias en Tolima y Huila, con pocos casos humanos. Se demostró la utilidad del hámster como animal centinela para captar la circulación viral en el ciclo enzoótico y se estudió la patología experimental en este animal, incluyendo técnicas ultraestructurales (11-13).

Entre 1969 y 1971, la enfermedad se extendió a Centroamérica, México y Texas, con considerables pérdidas en equinos y muchos casos clínicos en humanos. En México hubo 16.805 casos humanos, con 42 muertes atribuidas a la encefalitis equina venezolana (14). Hoy se cree que esta epizoodemia se debió a un virus vacunal, insuficientemente inactivado con formol $(15,16)$.

\section{El virus}

Realmente no se trata de un virus único, sino de una serie de virus muy similares en sus reacciones serológicas pero diferentes en su comportamiento biológico, de tal forma que se agrupan en un complejo taxonómico, el complejo del virus de la encefalitis equina venezolana (EEV), el cual está formado hasta la fecha por 13 miembros, todos aislados únicamente en el continente americano (tabla 1).
El complejo pertenece a la familia Togaviridae, género Alfavirus, el cual comprende viriones de $60 \mathrm{~nm}$ de diámetro, con nucleoide de RNA monocaternario, rodeado de una cápside iconsahédrica y de una envoltura, que toma de las membranas modificadas de las células que infecta (13) (figuras 5-6).

Los diferentes tipos y subtipos del virus obedecen a sus características antigénicas, a su distribución geográfica, a los huéspedes susceptibles y a las características patogénicas, entre otros factores. No todos son patógenos para los equinos.

El complejo de los EEV comenzó a perfilarse con cuatro subtipos iniciales (17), utilizando una prueba cinética de inhibición de la hemaglutinación. El subtipo I era el único que tenía un comportamiento biológico asociado con epizootias equinas y epidemias de encefalitis, por lo cual se conoce como epizoótico. Los subtipos II-IV se aislaban solamente de mosquitos y de pequeños roedores silvestres y no eran capaces de producir epizootias ni epidemias por lo cual se llamaron enzoóticos. Posteriormente, se han identificado otros dos subtipos con diferentes variedades serológicas,

Tabla 1. Complejo del virus de la encefalitis equina venezolana.

\begin{tabular}{|c|c|c|c|c|}
\hline Subtipo & Variedad & $\begin{array}{l}\text { Patrón de } \\
\text { transmisión }\end{array}$ & Región & Vectores \\
\hline \multirow[t]{5}{*}{1} & $A B$ & Epizoótico & Toda América & Mosquitos que pican mamíferos \\
\hline & $\mathrm{C}$ & Epizoótico & Toda América & Mosquitos que pican mamíferos \\
\hline & D & Enzoótico & $\begin{array}{l}\text { Centroamérica } \\
\text { y Suramérica }\end{array}$ & $\begin{array}{l}\text { Culex (Melanoconion) ocossa, } \\
\text { panocossa }\end{array}$ \\
\hline & $E$ & Enzoótico & Centroamérica & $\begin{array}{l}\text { Culex (Melanoconion) } \\
\text { taeniopus }\end{array}$ \\
\hline & $\mathrm{F}$ & Enzoótico & Brasil & Desconocido \\
\hline II (Everglades) & & Enzoótico & Sur de Florida & Culex (Melanoconion) cedecei \\
\hline \multirow[t]{4}{*}{ III } & A (Mucambo) & Enzoótico & Suramérica & Culex (Melanoconion) portesi \\
\hline & B (Tomate) & Enzoótico & Suramérica & Desconocido \\
\hline & B (Bijou Bridge) & Enzoótico & $\begin{array}{l}\text { Occidente de } \\
\text { Norteamérica }\end{array}$ & Oeciacus vicarus \\
\hline & $\mathrm{C}$ & Enzoótico & Perú & Desconocido \\
\hline IV (Pixuna) & & Enzoótico & Brasil & Desconocido \\
\hline V (Cabassou) & & Enzoótico & Guayana Francesa & Desconocido \\
\hline VI & & Enzoótico & Argentina & Desconocido \\
\hline
\end{tabular}

Tomado de: referencia 34 . 
Tabla 2. Encefalitis producidas por Alphavirus.

\begin{tabular}{|c|c|c|c|c|}
\hline & EEO $^{1}$ & EEE $^{1}$ & $\begin{array}{l}\text { EEV } 1 \\
\text { (epizoótica) }\end{array}$ & $\begin{array}{l}\text { EEV'1 } \\
\text { (enzoótica) }\end{array}$ \\
\hline Ciclo natural & Pájaros - Culex tarsalis & Pájaros - Culiseta melanura & Desconocido & $\begin{array}{l}\text { Roedores - Culex } \\
\text { (Melanoconion) }\end{array}$ \\
\hline $\begin{array}{l}\text { Vector de equinos } \\
\text { a humanos }\end{array}$ & Culex tarsalis & $\begin{array}{l}\text { Aedes sollicitans, } \\
\text { Coquilletidia perturbans }\end{array}$ & Muchos & Culex (Melanoconion) \\
\hline Amplificadores equinos & No & Posiblemente & Sí & No \\
\hline $\begin{array}{l}\text { Encefalitis humana } \\
\text { Encefalitis/infección }\end{array}$ & $\begin{array}{l}\text { Niños } 1 / 50 \\
\text { Adultos } 1 / 1.000\end{array}$ & $\begin{array}{l}\text { Niños } 1 / 17 \\
\text { Adultos } 1 / 40\end{array}$ & $<1 / 100$ & $?$ \\
\hline Edad & $\begin{array}{l}\text { Cualquiera (predilección } \\
\text { por infantes) }\end{array}$ & $\begin{array}{l}\text { Cualquiera (predilección } \\
\text { por niños) }\end{array}$ & Niños & $?$ \\
\hline Tasa de letalidad & $3-7 \%$ & $50-75 \%$ & $? 10 \%$ & $?$ \\
\hline Secuelas & $\begin{array}{l}\text { Comunes únicamente } \\
\text { en infantes }\end{array}$ & Comunes & Ocasionales & $?$ \\
\hline
\end{tabular}

${ }^{1}$ EEO: encefalitis equina del oeste; EEE: encefalitis equina del este; EEV: encefalitis equina venezolana. Tomado de: referencia 18.

dentro de los subtipos I y III. Actualmente hay evidencia de que las variedades $A$ y $B$ son idénticas y de que las variedades $D, E$ y $F$, del subtipo I no causan epizootias (tabla 2).

\section{Epidemiología}

Existen dos ciclos de transmisión viral, denominados enzoótico y epizoótico. En el primero, los reservorios del virus son pequeños roedores como Proechymis sp. y Oryzomis sp. dentro de los cuales el virus es transmitido por mosquitos del género Culex, subgénero Melanoconion (18); es propio de áreas húmedas, lluviosas y selváticas. Estos virus no son patógenos para los equinos y pueden causar enfermedad humana en personas que se introduzcan en este hábitat, enfermedad que en general es aguda, febril y benigna.

Se discute si mutaciones de este virus pueden originar las cepas patógenas propias del ciclo epizoótico. La evidencia epidemiológica, incluyendo la epidemiología molecular, sugiere que no es así $(16,19)$. En el ciclo epizoótico se afectan los equinos con gravedad variable según el tipo de virus y la vacunación previa. Los transmisores son numerosos mosquitos tales como Psorophora confinnis, Mansonia sp., Aedes scutelaris, Aedes serratus, Aedes taeniorhynchus, Anopheles aquasalisy varios más (8-10).
La aparición de los virus epizoóticos (variedades IAB y IC) no está bien definida. Puede proceder de reservorios involucrados en ciclos de transmisión silenciosa como los virus enzoóticos de aves migratorias, de animales infectados traídos de otras regiones, por administración de vacunas mal inactivadas o por incremento súbito en la densidad de vectores. No se ha confirmado la transmisión transovárica del virus en los mosquitos transmisores, hipótesis que explicaría este ciclo. La hipótesis que mayor fuerza tiene en la actualidad es que estos virus epizoóticos emergen por mutaciones que sufren las cepas enzoóticas. Existe evidencia basada en los análisis filogenéticos del EEV que generó la reciente epidemia/ epizoótica en Venezuela (1992-1993), el cual tiene linaje genético de la variedad enzoótica ID.

Una vez introducido en una área geográfica, el virus se establece allí y ocasiona epizootias periódicas que ocurren al final de las lluvias, usualmente cuando éstas han sido más intensas y prolongadas que en los años anteriores. El final de las lluvias coincide con la persistencia de aguas estancadas y mayor densidad de vectores.

Los animales más susceptibles son los asnos, los caballos y las mulas. También se infectan 
las aves, los reptiles, los perros (20), los cerdos, los caprinos, los ovinos y los vacunos (8), que no sufren la enfermedad, pero en los cuales se han demostrado títulos de anticuerpos altos contra el virus. Estos animales son importantes en la epidemiología de la enfermedad porque desvían los mosquitos hacia ellos y disminuyen la agresión a otros huéspedes, pero también algunos alcanzan viremas infectantes para el vector (20).

Los equinos son los principales amplificadores del virus desde los cuales la infección, a través del vector, se transmite al humano. Esta transmisión se facilita porque las viremias equinas son altas y prolongadas. En pocos días se infectan miles de personas y muchas desarrollan enfermedad febril aguda de gravedad variable.

La infección sin enfermedad posiblemente es alta, como se demuestra con los títulos de anticuerpos contra el virus en personas sanas, o que no estuvieron enfermas en las condiciones epidémicas (10).

\section{Patología}

En algunos huéspedes tales como el hámster, el curí y el conejo, la multiplicación viral destruye ampliamente el tejido linfoide central y periférico: médula ósea, bazo, timo, placas de Peyer, nódulos linfoides intestinales, ganglios linfáticos y tejido linfoide nasofaríngeo (13) (figuras 1-3). La lesión es muy severa, letal. No se produce encefalitis. Hay también daño pancreático exocrino, especialmente en el hámster (11-12) (figuras 4-7).

En otros huéspedes, como el ratón, los equinos y primates no humanos, el ciclo de multiplicación viral en el tejido linfoide es seguido de lá invasión y multiplicación del virus en el sistema nervioso central (21), al que llega por vías bien definidas, olfatorias y trigeminales $(22,23), 0$ por vía sanguínea, atravezando la barrera hematoencefálica en vesículas pinocitósicas del endotelio $(24,25)$. Es posible que el mayor daño encefálico se deba a reacción antígenoanticuerpo y no a multiplicación viral directa. El virus se puede aislar del SNC en la autopsia.

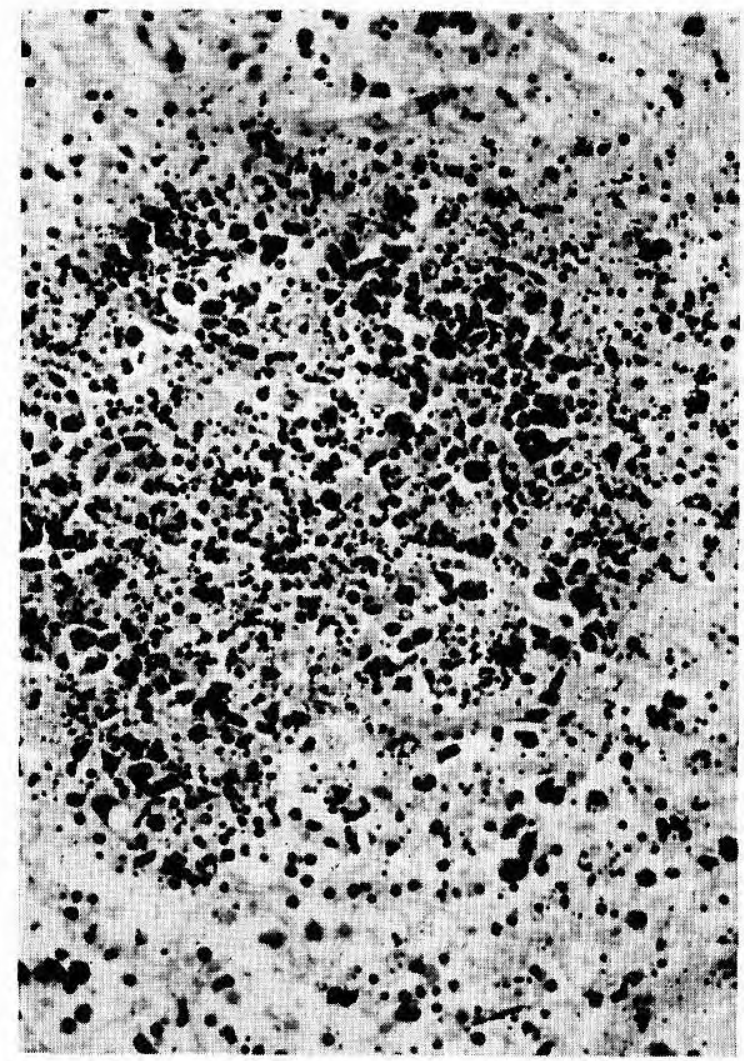

Figura 1. Necrosis masiva de un nódulo linfoide de un ganglio linfático de hámster, con enfermedad experimental por la cepa I-D del virus de la EEV.

La encefalitis es muy severa en los equinos (figuras 8-9), con edema cerebral, hemorragia y manguitos linfocitarios perivasculares con polimorfonucleares dispersos, dato éste que es útil en la sospecha etiológica, y vasculitis necrotizante severa $(13,26-27)$.

En el humano, la lesión linfoide también se presenta, pero es probablemente discreta. Existe una dilatación vascular y congestión generalizadas, sobre todo en el tracto gastrointestinal, que explica la ocurrencia de melenas. En los casos fatales con compromiso del SNC, el cerebro es muy edematoso, tiene áreas hemorrágicas microscópicas en la substancia blanca; la encefalitis es discreta o mínima, con cariorrexis en los linfocitos del infiltrado y en las células gliales.

En conclusión, las lesiones vistas en las autopsias de humanos muertos por EEV son 

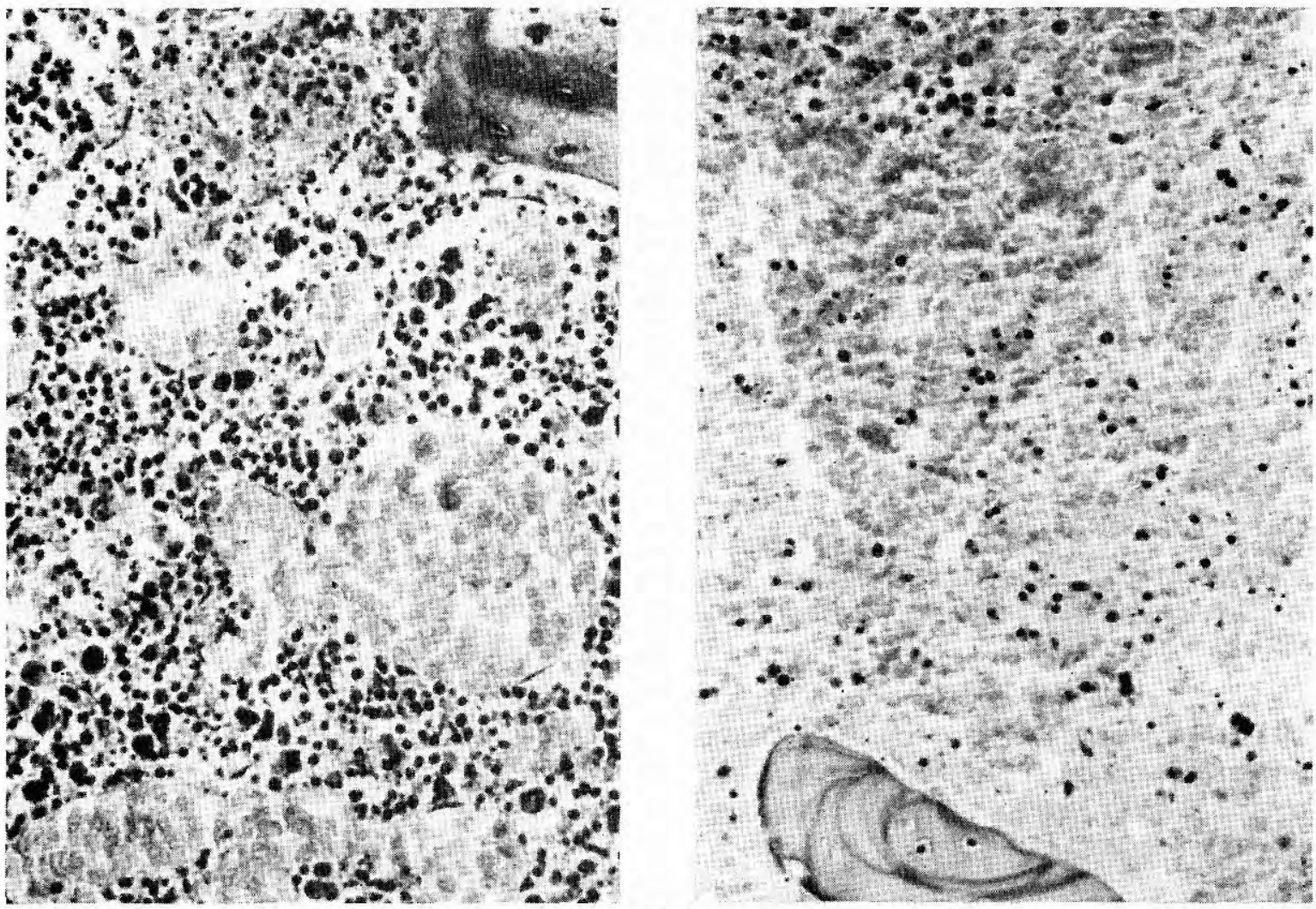

Figuras 2 y 3. Médula ósea de hámster con EEV experimental, cepa I-D. A la izquierda, en la fase incipiente de la enfermedad se aprecia congestión severa y focos de necrosis con cariorrexis; a la derecha, en fase más tardía, hay hemorragia extensa y notoria depauperación celular.

discretas y no conducen de una manera directa y específica al diagnóstico, pero sí permiten sospechar la entidad. El virus se puede aislar del cerebro, de la sangre y de otras vísceras. No disponemos de una técnica inmunológica que demuestre el virus o sus antígenos en los tejidos.

Una patología cerebral alarmante se ha observado en los fetos de madres que sufrieron la enfermedad en la epidemia del Zulia de 196264 (9, 28-29). En siete de ellos, con intervalo entre la enfermedad o infección materna y el parto de 15 días a 5 meses, el feto presentó necrosis cerebral masiva, con atrofia, reblandecimiento, hemorragia, microcefalia y microftalmia. Los fetos nacieron muertos o vivieron entre 15 minutos y 7 días, presentando disnea, bradicardia y convulsiones (9). Cualquier edad de gestación es susceptible a la infección viral. Experimentos con cepas diversas de virus, entre ellas la inoculación intracerebral a micos con la cepa vacunal TC-83, ha reproducido estas lesiones: microencefalia, hidrocefalia, cataratas y porencefalia $(29,30)$. Se demostró multiplicación del virus en diferentes tejidos fetales (30).

\section{Laboratorio}

Los estudios de laboratorio en la EEV muestran leucopenia importante en los primeros días de la enfermedad, tan baja como de 2.000 leucocitos $/ \mathrm{mm}^{3}$. Esta observación se ha precisado en la infección accidental de laboratorio y en la enfermedad natural $(6,31)$. A medida que pasa el tiempo, puede observarse leucocitosis pero los linfocitos representan un $20-25 \%$ del recuento total de glóbulos blancos. También se ha demostrado trombocitopenia $(18,31)$.

Los anticuerpos contra el virus se demuestran a partir del séptimo día de infección $(6,8)$. En 


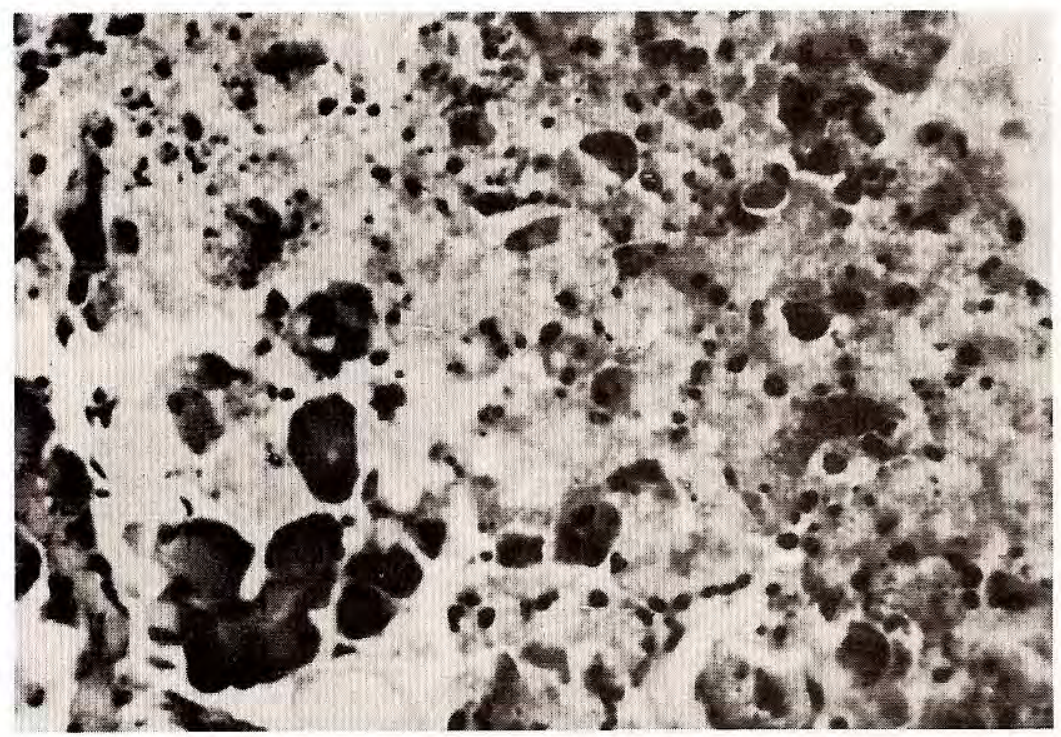

Figura 4. Páncreas de hámster con amplia necrosis con cariorrexis del componente exocrino. Enfermedad experimental con la cepa I-D de EEV.

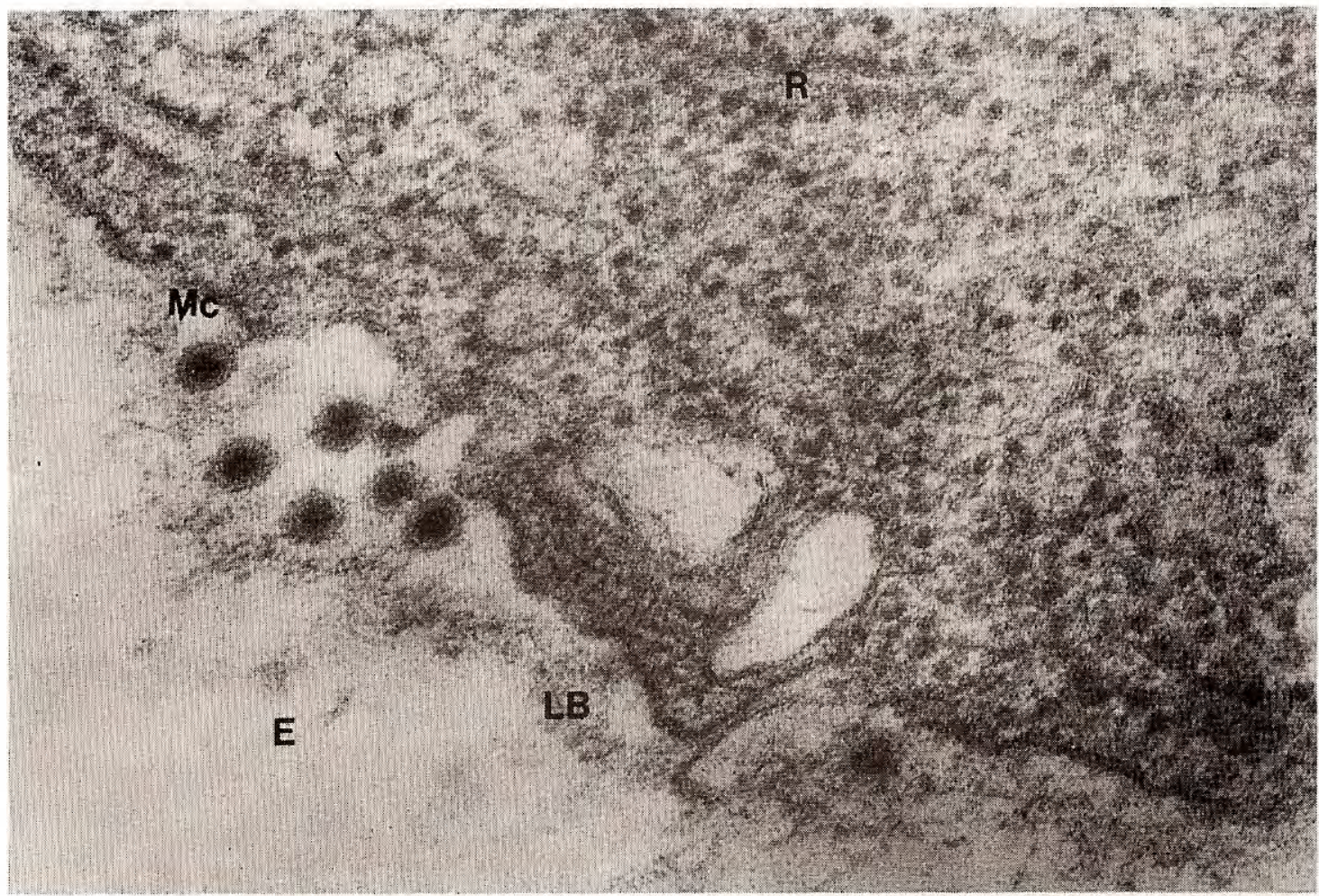

Figura 5. Porción basal de una célula pancreática exocrina del hámster. Los viriones de la EEV geman de la membrana plasmática (Mc), de la cual toman su envoltura. Nótese como rechazan la lámina basal (LB). R: retículo endoplásmico basal de la célula acinar; E: espacio extracelular. 


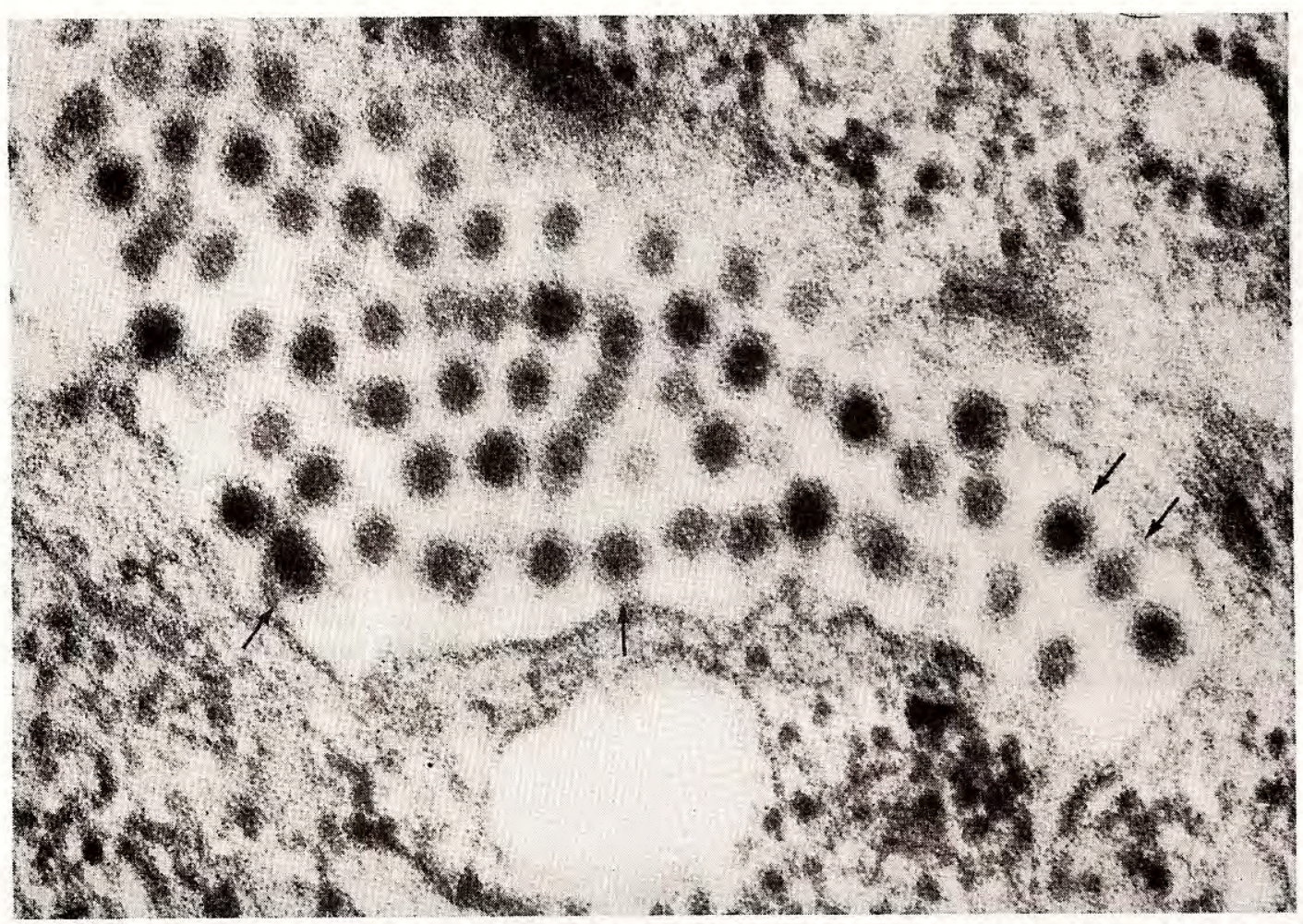

Figura 6. Acúmulos de viriones de la EEV entre dos células pancreáticas exocrinas del páncreas del hámster. Su nucleoide denso y su envoltura se demuestran con nitidez. Algunos viriones están gemando de la membrana celular (flechas).

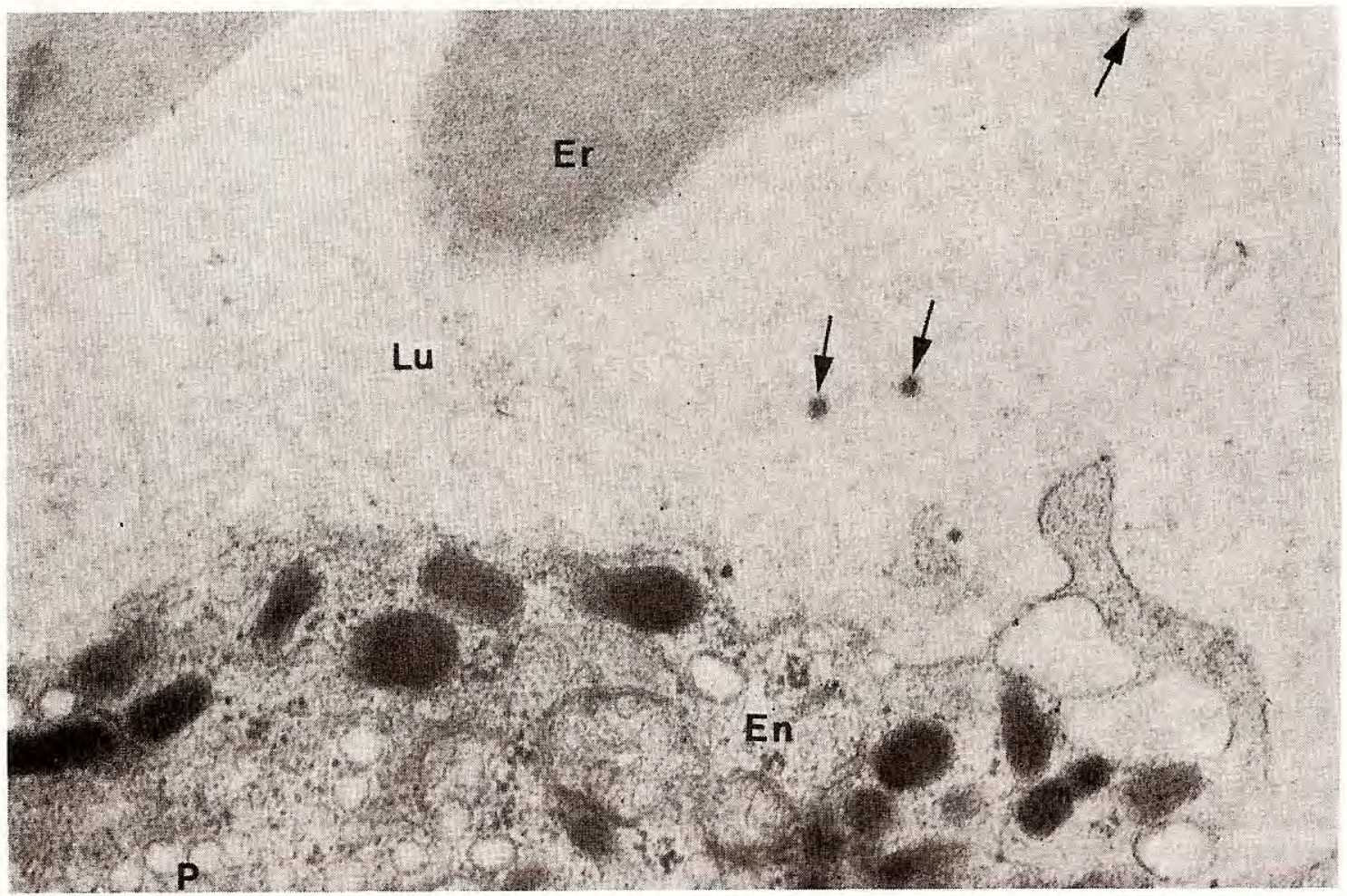

Figura 7. La viremia en la EEV es tan masiva que se ve aún en los cortes finos para microscopía electrónica (flechas). Lu: luz de la vénula; Er: eritrocito; P: vesículas de pinocitosis; En: célula endotelial de una vénula con numerosos gránulos densos de Weibel-Palade. 

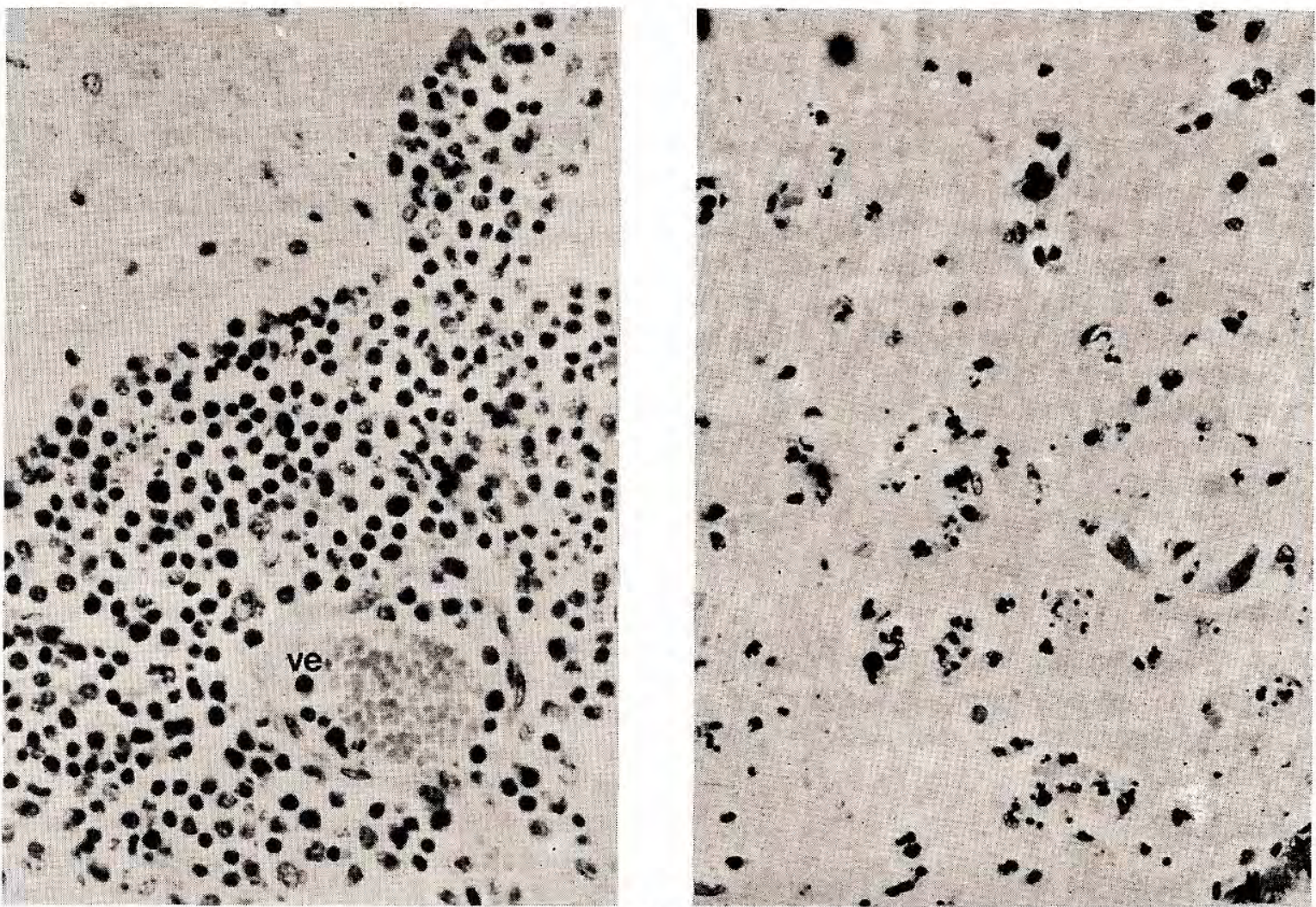

Figuras 8 y 9. Cerebro de caballo muerto por EEV. Infiltrado severo de linfocitos y algunos neutrófilos alrededor de una vénula (Ve). En la figura 9, el infiltrado es disperso con cariorrexis severa de los linfocitos, neutrófilos y células gliales. Las neuronas están bien preservadas.

las pocas veces en que se ha practicado punción lumbar, se ha demostrado pleocitosis con linfocitos y polimorfonucleares, hiperglucorraquia e hiperalbuminorraquia (31).

\section{Clínica}

Los Alfavirus producen en el hombre dos grandes síndromes clínicos: un síndrome febril agudo asociado con poliartritis y un síndrome febril agudo asociado con encefalitis.

El primero es producido por una decena de virus que circulan en Africa y Asia. En América, el único que plantea alguna importancia en la salud pública es el virus Mayaro, aislado por primera vez en Trinidad en 1954 (32), capaz de producir epidemias serias de poliartritis asociadas con fiebre, cefalea y mialgias, en Brasil y Bolivia.

El segundo síndrome es producido por tres virus que tienen neurotropismo exquisito y gran potencial de virulencia para el sistema nervioso central (tabla 2).

El periodo de incubación de la EEV, cuando la enfermedad humana se origina por contaminación en el laboratorio, es de $24-40$ horas y de 3-5 días en condiciones epidémicas (6). Los síntomas comienzan de manera abrupta, con malestar general, fiebre alta $\left(39-40^{\circ} \mathrm{C}\right)$, cefalea intensa de predominio frontal, escalofríos, dolores osteócopos y musculares, náusea, vómito y diarrea. Puede haber melenas, hematemesis, metrorragia, congestión conjuntival severa, dolor ocular y faringoamigdalitis.

La enfermedad se confunde con otras infecciones febriles agudas como dengue, dengue hemorrágico e, inclusive, fiebre amarilla. También se ha confundido con leptospirosis y con enfermedad diarreica aguda (18). Los niños menores de 10 años son los más severamente afectados y los que más presentan leta- 
lidad luego de síntomas y signos neurológicos, tales como convulsiones, excitación y coma.

La fiebre cede en 4-5 días y la enfermedad general en 1-2 semanas, persistiendo una astenia importante durante otras 1-2 semanas. La infección sin enfermedad es alta, posiblemente tres veces más alta que la sintomática (10). Se ha sugerido que la microcefalia, la hidrocefalia y la deficiencia mental pueden ser secuelas del daño cerebral, pero, sólo se ha demostrado con estudios epidemiológicos de casos y controles, una mayor frecuencia de epilepsia en 3 de 7 niños que sufrieron la EEV en la epidemia de Atuncelas en el municipio de Dagua, Valle del Cauca, en 1967 (33).

\section{Tratamiento}

No hay tratamiento antiviral específico. Las medidas de atención primaria incluyen reposo absoluto, hidratación adecuada y terapia sintomática.

\section{Inmunización}

La prevención se realiza mediante la vacunación periódica de los equinos en las áreas de riesgo.

En 1971, debido a que la infección con este virus es muy frecuente en los trabajadores de laboratorio, el Instituto Salk, Swiftwater, Pennsylvania, EUA, preparó cinco lotes de una vacuna de virus vivo atenuado, que llamó TC83, NDBR-102.

El virus inicial se aisló a partir de un burro de Trinidad y corresponde a la variedad IA. Se atenuó en cultivos celulares siguiendo un protocolo específico del mismo instituto. Una vez atenuado, se propagó en células primarias de corazón de curí.

La vacuna es el producto tratado y liofilizado, cosechado unas 30 horas después de inoculado el virus de semilla. Se reconstituye en agua estéril $y$, en el humano, se inoculan 0,5 $\mathrm{mL}$ por vía subcutánea. Como es un producto terapéutico aún experimental se aplica únicamente a personas altamente expuestas al virus por razones de trabajo y en forma voluntaria.
La experiencia actual indica que cerca del $5 \%$ de individuos vacunados fallan en el desarrollo de anticuerpos neutralizantes. Algunas de estas personas se han contaminado accidentalmente con virus homólogos de la EEV y desarrollaron síntomas leves de la enfermedad, los cuales se prolongaron por 24-36 horas.

En el equino, una sola inyección protege a más del $90 \%$ de los animales, con inmunidad que dura hasta por tres años (14).

\section{Diagnóstico de la actual epidemia de La Guajira, 1995}

El diagnóstico de la infección por EEV se hace aislando el virus a partir de muestras de suero, de escobillones faríngeos o de material de autopsia, tanto en equinos como en humanos. El virus se aisla en monocapas de células Vero, en las cuales produce un efecto citopático devastador en 24-48 horas. La identificación del virus se hace con pruebas de neutralización por el sistema de reducción de placas, utilizando sueros de referencia. La identificación en subtipos y variedades se hace por inmunofluorescencia (IF), con anticuerpos monoclonales.

Cuando el aislamiento no es posible, se recurre a pruebas serológicas para verificar la seroconversión. Las pruebas más usadas en la actualidad son las de inhibición de la hemaglutinación $(\mathrm{IH})$ y las pruebas de ELISA para detectar inmunoglobulina $\mathrm{M}$ antiviral.

En el curso de la actual epidemia de La Guajira (35), el Laboratorio de Virología del Instituto Nacional de Salud, ha aislado 21 cepas de virus de la EEV, a partir de sueros de personas agudamente enfermas, remitidos por el Departamento Administrativo de Salud de La Guajira, y el Ministerio de Salud. Se identificaron incialmente como alfavirus por IF con un líquido ascítico anti-EEV de referencia. Están en curso las pruebas de neutralización definitiva. Sin embargo, los primeros cuatro aislamientos fueron identificados por el doctor Scott Weaver como EEV subtipo IC, en el Departamento de Patología de la Facultad de Medicina de la Universidad de Texas, utilizando iniciadores (primers) específicos de ese subtipo. 
El genotipo de estos EEV, identificado por comparación de las secuencias de $\mathbf{8 2 0}$ nucleótidos localizados en un segmento del gene que codifica para la glicoproteína E2 (envoltura) es casi idéntico entre ellos y muy similar a los EEV que generaron la actual epidemia en Venezuela, a Ios EEV que causaron la epidemia en La Guajira, en 1961-1964 y a los generaron la epidemia en Venezuela en 1983.

En el Centro de Investigaciones en Salud y Producción Animal (CEISA) de la Corporación Colombiana de Investigación Agropecuaria (CORPOICA) de Bogotá, se han realizado pruebas de IH con antígeno EEV que han revelado anticuerpos de bajo título en personas con la enfermedad aguda, lo cual, asociado con la situación epidemiológica y epizoótica, tiene alto valor diagnóstico (L.A. Rocha, A. Guáqueta, comunicación personal). Además, se han realizado pruebas ELISA de captura para IgM equina estandarizadas en los laboratorios del ejército americano en Ft. Detrick (Jonathan F. Smith, Ph.D., Chief, Dept. of Viral Biology, U.S. Army Medical Research Institute of Infectious Diseases-USAMRIID) con resultados positivos.

\section{Conclusiones}

Los virus de la EEV están ampliamente distribuidos por todo el territorio colombiano. Se presentan epizootias y epidemias en ciclos irregulares, más frecuentes en La Guajira, la costa atlántica, Huila, Tolima y el Valle del Cauca.

EI doctor Guillermo Torres Moreno de la Universidad del Tolima, remitió al INS placas histológicas del cerebro de un equino con importantes cambios encefalíticos, junto con la información de que, al menos, 40 animales más habían muerto en la región del Putumayo con un cuadro clínico mieloencefalítico.

Estas señales de alarma demuestran la necesidad de vacunar periódicamente a los equinos contra la EEV, lo cual no sólo evita pérdidas económicas considerables sino que previene la enfermedad en los humanos.

La comunicación adecuada entre los laboratorios de salud humana y animal, coordinados eficientemente a través del Ministerio de Salud Pública, es una actividad necesaria y que debe propiciarse.

\section{Referencias}

1. Sanmartín C. Eldorado y los virus de las encefalitis. Conferencia presentada para admisión a la Sociedad Colombiana de Historia de la Medicina, Bogotá.

2. Albomoz VE La peste loca de las bestias. Boletín de Agricultura (Supl Min Agr y Com) 1935;26:1.

3. Kubes V, Ríos FA. The causative agent of infectious encephalitis in Venezuela. Science 1939;90:20.

4. Soriano A, Figueroa A. Aislamiento de un virus de un caballo atacado de "peste loca" en Bogotá. Bol Inst Nal Hig Samper Martínez (Bogotá) 1942;8:3.

5. Tiggertt WD, Dowuns WG. Studies of the virus of Venezuelan equine encephalomyelitis in Trinidad, W.I. I. The 1943-1944 epizootic. Am J Trop Med Hyg 1962;11:822.

6. Sanmartín-Barberi C, Groot H, Osorno-Mesa E. Human epidemic in Colombia caused by the Venezuelan equine encephalomyelitis virus. Am J Trop Med Hyg 1954;3:238.

7. Groot H. Estudios sobre virus transmitidos por artrópodos en Colombia. Rev Acad Col Ciencias exactas, físicas y nat 1964;12:197.

8. Sellers RF, Bergold GH, Suárez OM, et al. Investigations during Venezuelan equine encephalitis outbreaks in Venezuela 1962-1964. Am J Trop Med Hyg 1965;14:460.

9. Wenger F. Necrosis cerebral masiva del feto en casos de encefalitis equina venezolana. Invest Clin (Maracaibo) 1967;21:13.

10. Sanmartín C, Mackenzie R, Trapido H y col. Encefalitis equina venezolana en Colombia. Bol Oficina Sanit Panam 1967;64:108.

11. Rodriguez G, Romero M, Toro G y col. Encefalitis equina venezolna. Histopatología de la infección natural y experimental en el hámster. Rev Latin Pathol 1972;11:85.

12. Rodríguez G. Morphological change in the pancreas of the hamster during Venezuelan equine encephalomyelitis virus infection. Patología 1975;13:297.

13. Rodríguez G. Microscopía electrónica de la infección viral. Bogotá: Instituto Nacional de Salud, 1983.

14. McConell S. Venezuelan equine encephalomyelitis: past, present and future. J Amer Veter Med Ass 1972;161:1579.

15. Brown F. Review of accidents caused by incomplete inactivation of viruses. Dev Biol Stand 1993;81:103. 
16. Kinney RM, Tsuchiya KR, Sneider JM, et al. Molecular evidence for the origin of the widespread Venezuelan equine encephalitis epizootic of 1969-1972. J Gen Virol 1992;73:3301.

17. Young NA, Johson KM. Antigenic variants of VEE: their geographic distribution and epidemiologic singnificance. Am J Trop Med Hyg 1969;18:286.

18. Peters CJ, Dalrymple JM. Alphaviruses. In: Fields BN, Knipe DM et al, editors. Virology. New York: Raven Press, Ltd., 1990.

19. Sneider JM, Kinney R, Tsuchiya KR, et al. Molecular evidence that epizootic Venezuelan equine encephalitis viruses are not evolutionary derivatives of enzootic VEE subtype I-E or II viruses. J Gen Virol 1993;74:519.

20. Bivin WS, et al. Mosquito-induced infection with VEE in dogs. Am J Trop Med Hyg 1967;16:544.

21. Gleisser CA, Gochenour WS, Berge T, et al. The comparative pathology of experimental Venezuelan encephalomyelitis infection in different animal hosts. $J$ Infect Dis 1962;110:80.

22. Charles PC, Walters E, Margolis F, et al. Mechanism of neuroinvasion of Venezuelan equine encephalitis virus in the mouse. Virology 1995;208:662.

23. Jackson AC, SenGupta SK, Smith JF. Pathogenesis of Venezuelan equine encephalitis virus infection in mice and hamsters. Vet Pathol 1991;28:410.

24. García-Tamayo J. Acid phosphatase activity in mouse brain infected with Venezuelan equine encephalomyelitis virus. J Virol 1971;8:232.

25. Gorelkin L. Venezuelan equine encephalomyelitis in an adult animal host. An electron microscopic study. Amer J Pathol 1973;73:425.
26. Kissling RE, Chamberlain RW, Nelson DV, et al. Venezuelan equine encephalomyelitis in horses. Amer $\mathrm{J}$ Hyg 1956;63:274.

27. Robert ED, Sanmartín C, Payan J, et al. Neuropathologic changes in horses with naturally ocurring VEE. Am J Vet Rs 1970;31:1223.

28. Wenger F, Molero L, Fereira $\mathbf{H}$ y col. Encefalitis equina venezolana. Investigación clínica (Maracaibo) 1967;21:69.

29. García-Tamayo J. Efecto teratogénico del virus de la encefalitis equina venezolana. Revisión del problema. Invest Clin 1992;33:81.

30. London WT, Levitt HN, Stephen G, et al. Congenital cerebral and ocular malformations induced in Rhesus monkeys by VEE virus. Teratology 1977;16:285.

31. Pellacani D, Soto E. Encefalitis equina venezuela. Estudio clínico y de laboratorio en pacientes pediátricos. Invest Clin 1973;14:145.

32. Anderson CR, Downs WG, et al. A new human disease agent. II. Isolation from patients in Trinidad. Am J Trop Med Hyg 1957;6:1012.

33. León CA, Jaramillo R, Martínez S y col. Secuelas de la encefalitis equina venezolana en humanos: seguimiento epidemiológico de cuatro años. Acta Med Valle 1975;6:114.

34. Walton TE, Grayson MA. Venezuelan equine encephalomyelitis. In: Monath TP, editor. The Arboviruses: epidemiology and ecology. Boca Ratón: CRC Press, 1988:203-233.

35. IQCB, Ministerio de Salud, Instituto Nacional de Salud. Encefalitis equina venezolana (EEV) en La Guajira, Colombia, septiembre 1995, 1995;1:9-15. 